\title{
Growth and Metabolic Responses of Rhazya stricta Decne to Habitat Diversity in Makkah Region, Saudi Arabia
}

\author{
Amal M. Abdel-Rahman ${ }^{(1) \#}$ and Muna Almalki( ${ }^{(2)}$ \\ ${ }^{(1)}$ Department of Botany \& Microbiology, Faculty of Science Alexandria University, \\ Alexandria, Egypt and ${ }^{(2)}$ Department of Biological Sciences, Faculty of Science, Umm \\ Al-Qurah University, Makkah, Saudi Arabia.
}

$\mathbf{T}$

HE PRESENT study is an attempt to clarify the effect of habitat (Mountain, plain and wadi) diversity on growth behavior and metabolic activities of one common perennial dwarf shrub (Rhazya stricta). Plain was attained the highest moisture availability and lowest salt stress while the highest content of coarse sand recorded in wadi which led to loss water, mountain holds in its notches an adequate amount of moisture for growth of some species. Leaf area, height of plant, crown diameter, and the biomass of above ground organs furthermore, abundance measurements (absolute density, frequency and cover) were significantly varied with habitat types. The favorable habitat types for the plant growth and productivity were plain and wadi as compared with mountain. Carbohydrates and proteins (total and soluble) in different phenophases of plant were significantly varied with habitat types. The highest essential elements in all studied habitats for the plant organs (root, leaves) were $\mathrm{Ca}$ and $\mathrm{K}$. In mountain $\mathrm{K} / \mathrm{Na}$ ratio is low in mountain compared with the other habitats. This result may indicate that the plant in mountain use sodium as osmoregulatory substance, while in plain and wadi the contribution of $\mathrm{K}$ to the osmotic balance is larger than $\mathrm{Na}$. Total flavonoids, total phenolics and essential oil were accumulated more in the plant which grow under sever mechanical stress (mountain habitat type).

Keywords: Rhazya stricta, Habitats, Growth, Metabolites, Phytochemical compounds.

\section{Introduction}

In the natural environment, plants often grow under unfavorable conditions, such as salinity, drought, freezing, chilling, high temperature, or flooding. These conditions are known collectively as abiotic stresses, and any of them can delay growth and development, reduce productivity and, in extreme cases, cause the plant to die (Tony \& Norio, 2002). Plant stress responses are dynamic and involve complex cross-talk between different regulatory levels, including adjustment of metabolism and gene expression for physiological and morphological adaptation (Krasensky \& Jonak, 2012). Studies of growth and metabolic responses of desert plants within their natural habitats as well as comparisons of these responses can be considered of great value in understanding the behavior by which these plants adjust to their habitats (Raven \& Johnson, 2002). Rhazya stricta Decne (Apocynaceae) is a perennial evergreen dwarf shrub widely distributed in Western and South Asia and is well adapted to harsh condition
(Gilani et al., 2007). Migahid (1996) stated that this species is widely distributed in Saudi Arabia. Its geographical distribution extends partially into all the phytogeographical regions of the country. The species was recorded in a variety of habitats; rocky, hills, plains, depressions and wadis (Chaudhary \& Al-jowaid, 1999). The appearance of $R$. stricta depends upon its habitat. The shrub is stunted and yellowish-green where the soil is formed of coarse materials and rainfall is low, but is bigger and dark green where the soil is fine and water is in abundance (Zahran, 2010).

The study area has a hot desert climate like almost all places the Arabian Peninsula, temperature in winter, which can range from $18^{\circ} \mathrm{C}$ at night to $30^{\circ} \mathrm{C}$ in the day. Summer temperatures are extremely hot, often being over $40^{\circ} \mathrm{C}$ during the day, dropping to $30^{\circ} \mathrm{C}$ at night. Rain usually falls in Makkah in small amounts between November and January. The average precipitation is very low with only $40 \mathrm{~mm}$ a year (1.5 inch). The amount of

\#Corresponding author email: elmasry_amal@yahoo.com 
rain fall varies considerably around this mean from one year to the other. The rainfall, as scant as it is, also presents the threat of flooding and has been a danger since the earliest times. The average relative humidity over the year attained its maximum average of $60 \%$ in winter and its minimum average of $40 \%$ in summer (Meteorology \& Environment, 1992). Many physiographic locations may be distinguished due to the variability of edaphic, topographic and geomorphologic features.

The present study aims to discuss growth behavior of $R$. stricta which representing by different growth parameter and distribution as well as some physiological variations in different desert habitat types in Makkah region.

\section{Material and Methods}

Plant and soil samples were collectedrandomly from different habitats; mountain, plain and wadi. They are Arafat, Al -Shemisy and wadi El Raian (Fig. 1). The plant species selected for study Rhazya stricta which represent common perennial dwarf shrub in Makkah region. During the period of study which started in November 2008 at different phenological phases; vegetative; flowering and fruiting till April 2009. During this period a number of different individuals size (at least 5 individuals) were collected randomly from several locations in each habitat. All samples were kept in paper bags and brought to the laboratory after collection, where they were washed with tap water, then by distilled water and air dried. The sampled of plant individuals were separated into roots, branches, leaves, flowers and fruits. All plant samples were oven dried at $60^{\circ} \mathrm{C}$ to constant weight. The samples were then ground, powdered and kept in paper bags ready for analysis.

Three soil samples $(0-30 \mathrm{~cm}$ depth $)$ were collected in different locations of each habitat and these samples were pooled to determined soil characters. Soil texture according to Kilmer \& Alexander (1949). The $\mathrm{pH}$ and EC were measured in soil water extract (1:5 weight:volume) using $\mathrm{pH}$ and electrical conductivity meter also soluble cations $\left(\mathrm{Na}^{+}, \mathrm{K}^{+}, \mathrm{Ca}^{++}, \mathrm{Mg}^{++}\right)$and anions $\left(\mathrm{P}^{---}, \mathrm{N}\right.$, $\mathrm{Cl}^{-}$) were determined according to the method for soil analysis to Allen et al. (1984).

The organs biomass (branches, leaves, flowers, fruits) per individual was determined as gram dry weight/individual through different phases of growth. Vegetation analysis was determined in vegetative phase. Absolute density and frequency per $100 \mathrm{~m}^{2}$ for the studied plant were estimated quantitively by quadrate method while cover was estimated by line- intercept method (Causton, 1988). The production of above ground part $\left(\mathrm{gm} / 100 \mathrm{~m}^{2}\right)$ for $R$. stricta in each habitat was then calculated by multiplying the mean biomass (for different phases/individual) by the absolute density. The average leaf length $(\mathrm{cm})$ and leaf width $(\mathrm{cm})$ through vegetative phase were used to calculate the leaf area according to Larcher (1995).

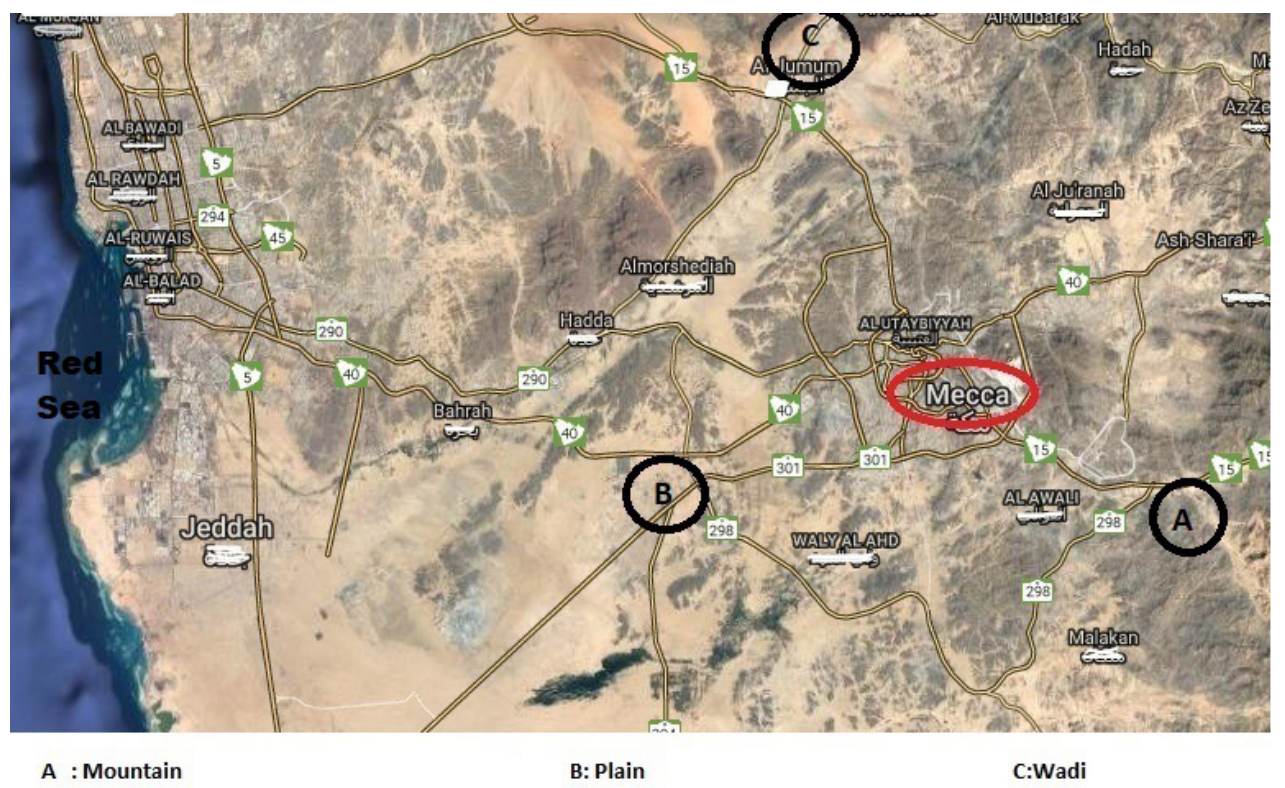

Fig. 1. Location map of the study area. 
Total available carbohydrates (TAC) and total soluble sugars (TSS) were estimated according to Nelson (1944) and Naguib (1964). Total protein (TP) and soluble protein (SP) were estimated according to Lowery et al. (1951) and Hartree (1972). During vegetative phase plant samples of fresh leaves were collected in each habitat for determination of pigment content (chlorophyll a, chlorophyll b, carotenoids) according to Lichtenthaler (1987).

Essential elements ( $\mathrm{Ca}, \mathrm{Mg}, \mathrm{Na}, \mathrm{K}$, and $\mathrm{P}$ ) for roots and leaves estimated according to Allen et al. (1984), phytochemicals; test for sterols, tannins, flavonoids, coumarins and alkaloids were carried out according to the methods described by Harborne $(1973,1998,1999)$ respectively. Additionally, glycosides, saponins, were detected by the procedures of Farnsworth (1966) and Lewis \& Smith (1967), respectively. On the other hand, the content of total phenols and flavonoids was determined according to Meda et al. (2005) while extraction and estimation of essential oils followed the method described by Odalo et al. (2005).

Results obtained were treated statistically by applying one-way analysis of variance for studied species in the different habitats where they are recorded accordingto Zar (1984).

\section{Results}

Soil characteristics of the selected habitats in this study are summarized in Table1. Soil texture, soil moisture \%, essential elements (mg/L) such as $\mathrm{Mg}^{++}, \mathrm{Na}^{+}, \mathrm{K}^{+}$and $\mathrm{Cl}^{-}$showed significant variations $(p<0.05)$ between habitat types. Results of soil texture analysis showed that, sand \% ranges from 76.8 in mountain to 85.2 in plain while clay \% has the lowest fraction; it ranges from 2.9 in plain to 8.6 in mountain. The data in Table 2 showed that $\mathrm{Ca}^{++}$and $\mathrm{Cl}^{-}$content exhibited a wide range of variation. $\mathrm{Ca}^{++}$varies between $10.1 \mathrm{mg} / \mathrm{L}$ in plain and $17.9 \mathrm{mg} / \mathrm{L}$ in wadi but $\mathrm{Cl}^{-}$varies between 9 $\mathrm{mg} / \mathrm{L}$ in wadi and $32 \mathrm{mg} / \mathrm{L}$ in mountain. Narrow range of variation shows in $\mathrm{P}$ and $\mathrm{N}$ content in the three different habitats. The variation in the contents of monovalent cations $\left(\mathrm{Na}^{+}\right.$and $\left.\mathrm{K}^{+}\right)$and divalent cations $\left(\mathrm{Ca}^{++}\right.$and $\left.\mathrm{Mg}^{++}\right)$affect their ratios together in the soil of different habitats. The ratios of $\mathrm{Na}^{+} / \mathrm{K}^{+}$and $\mathrm{Ca}^{++} / \mathrm{Mg}^{++}$indicated that $\mathrm{Na}^{+}$and $\mathrm{Ca}^{++}$content was greater than $\mathrm{K}^{+}$and $\mathrm{Mg}^{++}$content (greater than unity) except in wadi $\mathrm{K}^{+}$content more than $\mathrm{Na}^{+}$(Table1). The highest soil moisture was in plain $2.37 \%$ and the lowest in wadi $0.87 \%$.

The biomass (g.d.wt./ind.) in different above ground organs of $R$. stricta in the different studied habitats are illustrated in Fig. 2. The highest biomass for all above ground organs were attained in plain, while the lowest was recorded in mountain.

The distribution of $R$. stricta in different habitats represented by its absolute density, frequency and cover are presented in Table 2. Notably, $R$. stricta was available frequently in wadi and plain habitats. Accordingly, the maximum production/100 $\mathrm{m}^{2}$ was recorded in wadi, while the minimum one was recorded in mountain habitat.

Leaf area $\left(\mathrm{cm}^{2}\right)$, plant height $(\mathrm{cm})$ and crown diameter $(\mathrm{cm})$ at vegetative phase in the different habitats are illustrated in Fig. 3. All these parameters attained the highest and lowest values in plain and mountain, respectively.

TABLE 1. Mean values of the physical and chemical characters of the soil at the depth of $(0-30 \mathrm{~cm})$ in different habitats of the study area.

\begin{tabular}{|c|c|c|c|c|c|c|c|c|c|c|c|c|c|c|c|c|}
\hline Habitats & $\begin{array}{c}\text { Coarse } \\
\text { Sand } \\
(\%)\end{array}$ & $\begin{array}{c}\text { Fine } \\
\text { sand } \\
(\%)\end{array}$ & $\begin{array}{l}\text { Silt } \\
(\%)\end{array}$ & $\begin{array}{l}\text { Clay } \\
(\%)\end{array}$ & $\begin{array}{c}\text { Soil } \\
\text { moisture } \\
(\%)\end{array}$ & pH & $\begin{array}{c}\text { EC us/ } \\
\mathrm{cm}\end{array}$ & $\mathbf{C a}^{++}$ & $\mathbf{M g}^{++}$ & $\begin{array}{l}\mathrm{Ca}^{+} / \\
\mathrm{Mg}^{++}\end{array}$ & $\mathrm{Na}^{+}$ & $\mathbf{K}^{+}$ & $\begin{array}{c}\mathrm{Na}^{+} / \\
\mathbf{K}^{+}\end{array}$ & $\mathbf{P}$ & $\mathbf{N}$ & $\mathrm{Cl}^{-}$ \\
\hline A & $28.4^{\mathrm{b}}$ & $48.4^{b}$ & $14.6^{\mathrm{c}}$ & $8.6^{\mathrm{c}}$ & $1.29^{\mathrm{b}}$ & $7.19^{a}$ & $1.46^{\mathrm{b}}$ & $17.8^{\mathrm{b}}$ & $1.5^{\mathrm{a}}$ & 11.87 & $6.5^{\mathrm{b}}$ & $4.7^{\mathrm{a}}$ & 1.38 & $0.27^{\mathrm{a}}$ & $2.5^{\mathrm{a}}$ & $32^{\mathrm{c}}$ \\
\hline B & $21.0^{\mathrm{a}}$ & $64.2^{\mathrm{c}}$ & $11.9^{\mathrm{b}}$ & $2.9^{\mathrm{a}}$ & $2.37^{\mathrm{c}}$ & $6.9^{\mathrm{a}}$ & $1.37^{\mathrm{a}}$ & $10.1^{\mathrm{a}}$ & $2.9^{c}$ & 3.48 & $9.5^{\mathrm{c}}$ & $5.7^{\mathrm{b}}$ & 1.67 & $0.25^{\mathrm{a}}$ & $2.9^{\mathrm{a}}$ & $14^{\mathrm{b}}$ \\
\hline $\mathrm{C}$ & $49.1^{\mathrm{c}}$ & $34.2^{\mathrm{a}}$ & $10.2^{\mathrm{a}}$ & $6.5^{\mathrm{b}}$ & $0.87^{\mathrm{a}}$ & $7.3^{\mathrm{a}}$ & $1.48^{\mathrm{b}}$ & $17.9^{\mathrm{b}}$ & $2.1^{\mathrm{b}}$ & 8.52 & $5.1^{\mathrm{a}}$ & $7.3^{\mathrm{c}}$ & 0.70 & $0.29^{\mathrm{a}}$ & $2.9^{\mathrm{a}}$ & $9^{\mathrm{a}}$ \\
\hline
\end{tabular}


TABLE 2. Mean values of absolute density, frequency, cover and production/100 $\mathrm{m}^{2}$ of Rhazya stricta in three different habitats of the study area.

\begin{tabular}{|c|c|c|c|c|}
\hline Habitat & $\begin{array}{c}\text { Absolute } \\
\text { density }\end{array}$ & $\begin{array}{l}\text { Absolute } \\
\text { frequency }\end{array}$ & Cover & Production \\
\hline A & 10.5 & 40 & 2.86 & 2832 \\
\hline B & 18 & 52 & 3.63 & 19937 \\
\hline $\mathrm{C}$ & 40 & 68 & 4.18 & 32088 \\
\hline
\end{tabular}

-A: Mountain, B: Plain, C: Wadi

Chlorophyll a, chlorophyll $\mathrm{b}$ and carotenoid contents in fresh leaves of $R$. stricta through vegetative phase are shown in Fig. 4. The order of variations in photosynthetic pigments was chl a $>$ chl b $>$ carotenoids. Results also revealed that; the lowest content of chlorophyll $\mathrm{a}$ and $\mathrm{b}$ was recorded in plain and no great difference was obvious between mountain and wadi habitats. The content of carotenoids exhibited a little variation between all studied habitat types.

The pattern of carbohydrates content (TAC and TSS) in different organs of $R$. stricta during different phenophases indicated that, there was a significant variation with habitat type (Table 3 ).

The minimum content of TAC was recorded in leaf organ during fruiting phase in the habitat of mountain, while the maximum one was recorded in the roots during flowering phase in the habitat of plain. The highest content of TSS was recorded in the habitat of mountain in flowers. Generally, the content of TAC in most plant organs in habitat of plain was greater than in the other habitats (Table 3).

The protein content (TP and SP) in most plant organs during different phenophases varied significantly with habitat type (Table 4). $R$. stricta grown in mountain habitat type was characterized by high content of total protein through different phenological phases. Within all different phenophases, it is obvious that total and soluble protein in most plant organs tend to accumulate from vegetative to flowering phase especially in mountain habitat type, but there was no remarkable trend in SP content with the variation in habitat type.

Results in Table 5 showed that $\mathrm{Ca}^{+2}$ and $\mathrm{K}^{+}$were the most remarkable elements in both organs (roots, leaves) of the studied plant in all habitats. Mountain habitat attained the highest content of $\mathrm{Na}^{+}$, while in plain the highest content was $\mathrm{K}$ and $\mathrm{P}$.
The qualitative active phytochemical screening in roots and leaves of the studied plant were varied in different habitats (Table 6). These compounds were higher in mountain than in plain and wadi.

The quantitative data for secondary compounds in Table 7 showed that total phenolic compounds (\%) were the highest one followed by total flavonoids (\%) and the lowest was alkaloids for both roots and leaves in all habitats. It is obvious that these compounds were higher in mountain habitat than in the other habitats type.Essential oil was very low of the studied plant in all habitats.

\section{Discussion}

The behavior of desert plants in relation to the environmental factors is a complicated mechanism with which these plants regulate the expenditure of moisture necessary for growth and metabolic processes. These plants are often exposed to extreme stress factors such as drought, temperature, nutrient deficiency, salinity and mechanical stress; therefore, they show an extraordinary individual flexibility of structure, physiologic metabolic processes and the accumulation of specific biochemical metabolites (Hale \& Orcutt, 1987). Abiotic factors are often interrelated, either individually or in combination, they cause morphological, physiological, biochemical, and molecular changes that adversely affect plant growth and productivity, and ultimately yield (Bita \& Gerats, 2013). Generally, plant growth and its biomass allocation are two most fundamental processes of plants, being remarkably influenced by environmental variables including water changing factor (Chaves, 2003). Expectedly, wadis harbor $R$. stricta species characterized by maximum growth, absolute frequency, density and cover as well as production index which may be attributed to soil texture (Mesdaghi, 1995) as well as high content of $\mathrm{Ca}^{++}, \mathrm{K}^{+}$and low content of moisture, silt, $\mathrm{Na}^{+}$ and $\mathrm{Cl}^{-}$and their minimum in mountain where the soil was loamy sand and contain lower content of $\mathrm{Mg}^{++}, \mathrm{K}^{+}, \mathrm{N}$ but high content of $\mathrm{Cl}^{-}$. 

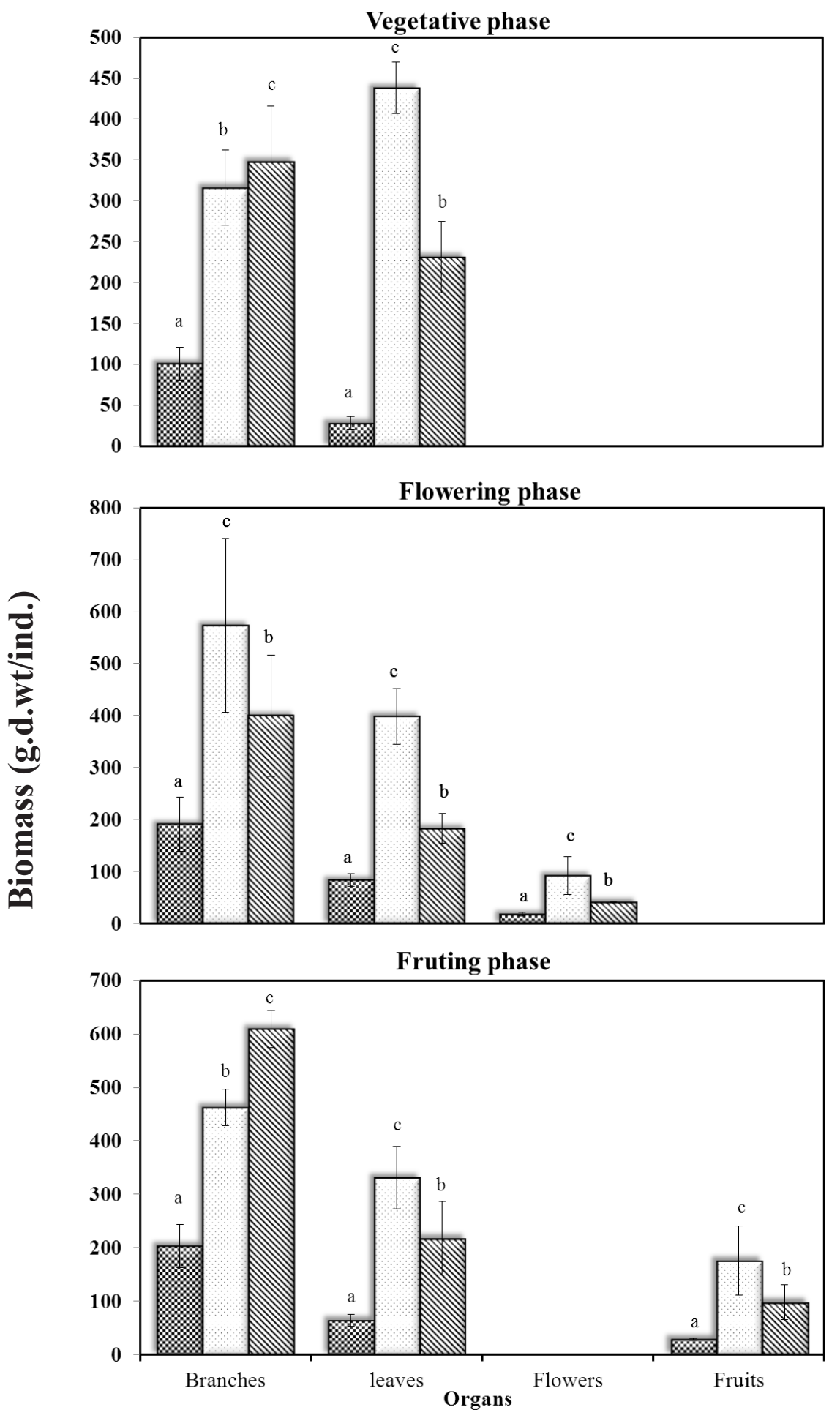

Mountain $\quad \because$ Plain Wadi

Fig. 2. Variations in biomass (g.d.w./ind) in different organs of Rhazya stricta at different phases in different habitats of the study area. (Different letters respecting the three different habitats indicate a significant difference at the 0.05 level of probability as evaluated by analysis of variance). 


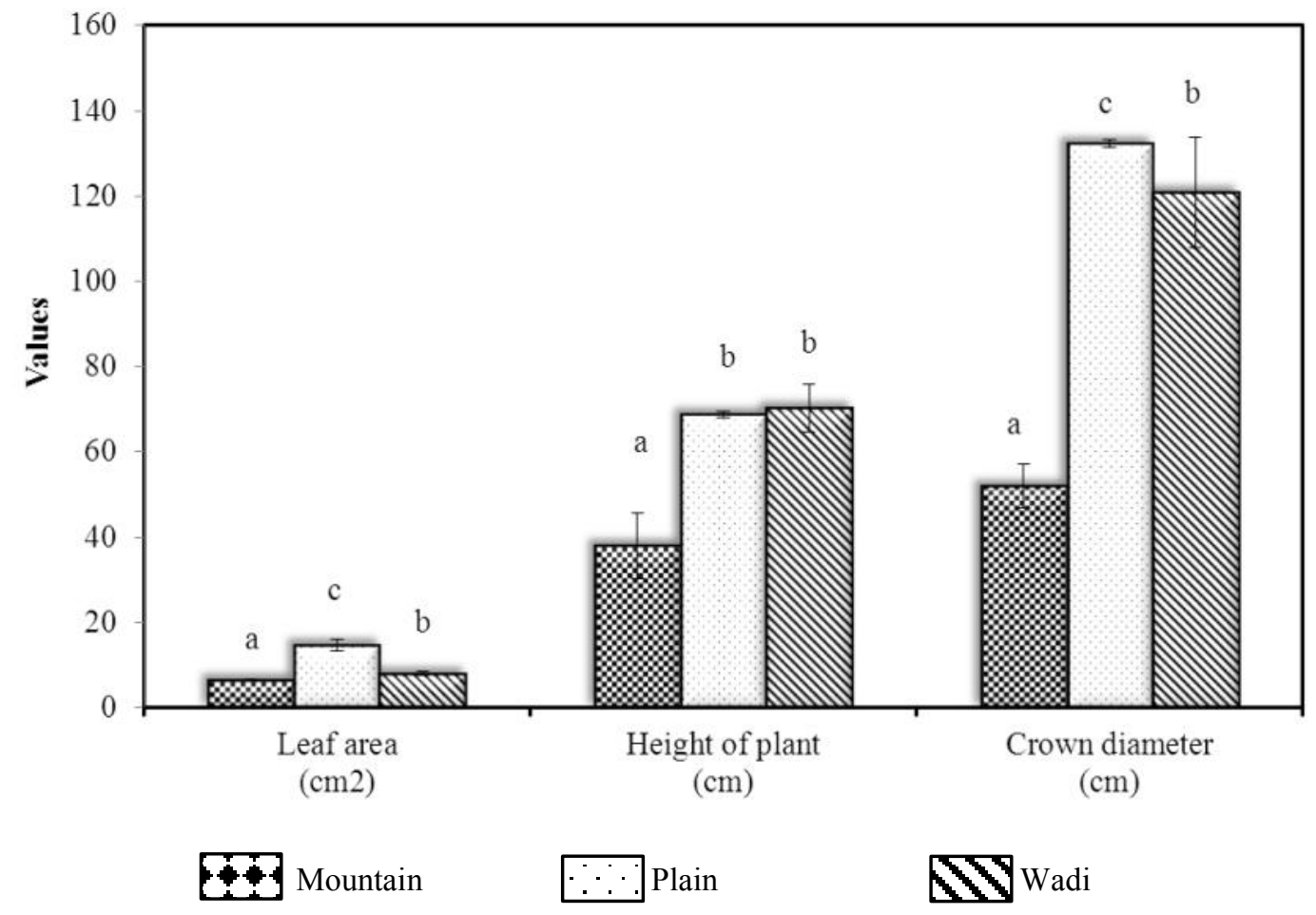

Fig. 3. Variations in some morphological characters of Rhazya stricta in different habitats of the study area. (Different letters respecting the three different habitats for each parameter indicate a significant difference at the 0.05 level of probability as evaluated by analysis of variance).
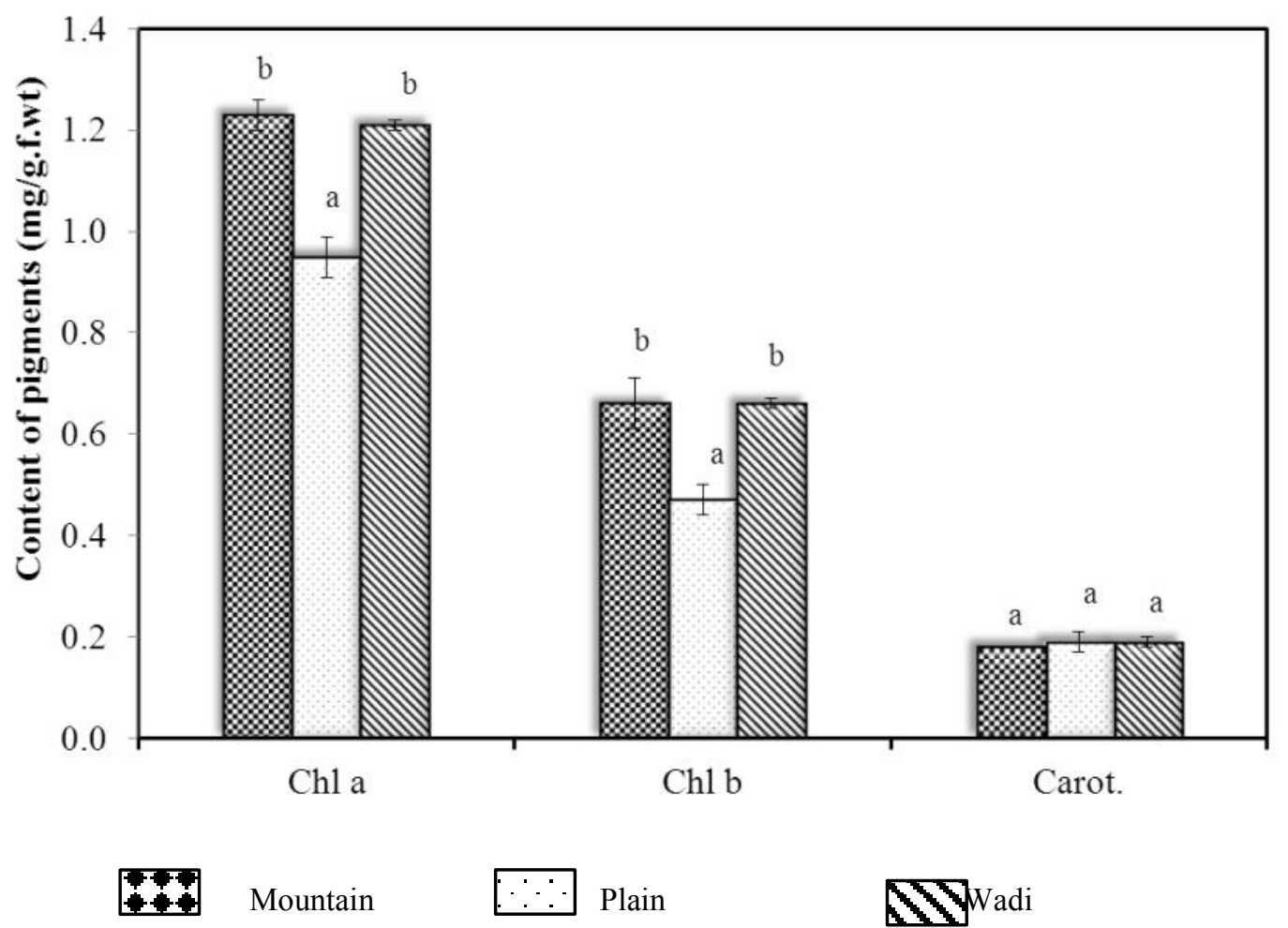

Fig. 4. Variations in photosynthetic pigments (mg/g.f.wt) in leaves of Rhazya stricta in different habitats at vegetative phase. (Different letters respecting the three different habitats for each parameter indicate a significant difference at the 0.05 level of probability as evaluated by analysis of varian). 
TABLE 3. Variations in the mean concentration (mg/g.d.wt) \pm SD of carbohydrates in different organs of Rhazya stricta during three phenophases in different habitats.

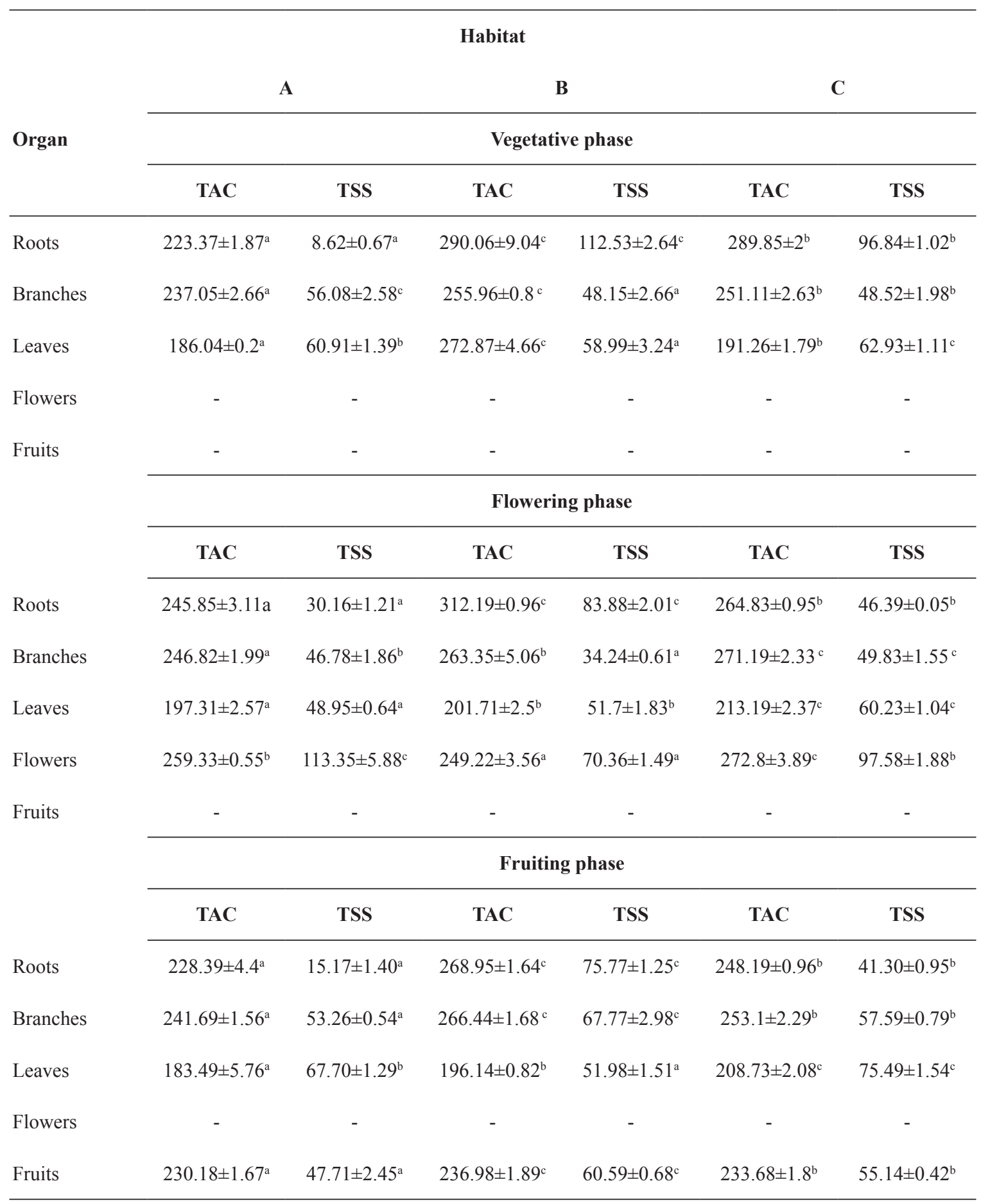

-A: Mountain, B: Plain, C: Wadi

-TAC: total available carbohydrates

-TSS: total soluble sugar

-Different letters for each organ respecting the three different habitats for each parameter indicate a significant difference at the 0.05 level of probabilityas evaluated by analysis of variance. 
TABLE 4. Variations in the mean concentration (mg/g.d.wt) \pm SD of proteins in different organs of Rhazya stricta during three phenophases in different habitats.

\begin{tabular}{|c|c|c|c|c|c|c|}
\hline \multicolumn{7}{|c|}{ Habitat } \\
\hline \multirow{3}{*}{ Organ } & \multicolumn{2}{|c|}{$\mathbf{A}$} & \multicolumn{2}{|c|}{ B } & \multicolumn{2}{|c|}{$\mathbf{C}$} \\
\hline & \multicolumn{6}{|c|}{ Vegetative phase } \\
\hline & TP & SP & TP & SP & TP & SP \\
\hline Roots & $98.21 \pm 3.18^{\mathrm{c}}$ & $31.44 \pm 2.15^{\mathrm{a}}$ & $74.48 \pm 0.78^{\mathrm{a}}$ & $62.40 \pm 0.95^{\mathrm{c}}$ & $82.12 \pm 4.95^{\mathrm{b}}$ & $48.53 \pm 0.64^{\mathrm{b}}$ \\
\hline Branches & $113.24 \pm 6.00^{\mathrm{c}}$ & $73.29 \pm 1.47^{\mathrm{b}}$ & $99.46 \pm 2.38^{\mathrm{b}}$ & $67.6 \pm 1.31^{\mathrm{a}}$ & $96.89 \pm 1.65^{\mathrm{a}}$ & $67.6 \pm 0.59^{\mathrm{a}}$ \\
\hline Leaves & $162.47 \pm 2.22^{\mathrm{b}}$ & $139.08 \pm 4.52^{\mathrm{b}}$ & $165.35 \pm 8.51^{\mathrm{c}}$ & $152.03 \pm 0.00^{c}$ & $154.96 \pm 9.66^{\mathrm{a}}$ & $135.1 \pm 0.82^{\mathrm{a}}$ \\
\hline Flowers & - & - & - & - & - & - \\
\hline \multirow[t]{3}{*}{ Fruits } & - & - & - & - & - & - \\
\hline & \multicolumn{6}{|c|}{ Flowering phase } \\
\hline & TP & SP & $\mathbf{T P}$ & SP & TP & SP \\
\hline Roots & $140.48 \pm 3.15^{\mathrm{c}}$ & $59.45 \pm 1.27^{\mathrm{a}}$ & $100.9 \pm 1.34^{\mathrm{a}}$ & $84.85 \pm 1.11^{\mathrm{c}}$ & $110.44 \pm 3.31^{\mathrm{b}}$ & $60.75 \pm 0.36^{\mathrm{b}}$ \\
\hline Branches & $114.55 \pm 1.39^{\mathrm{c}}$ & $79.38 \pm 1.63^{\mathrm{c}}$ & $97.73 \pm 0.48^{\mathrm{b}}$ & $59.29 \pm 1.08^{\mathrm{b}}$ & $89.51 \pm 1.57^{\mathrm{b}}$ & $53.16 \pm 0.59^{\mathrm{a}}$ \\
\hline Leaves & $166.82 \pm 0.00^{\mathrm{b}}$ & $150.8 \pm 1.23^{\mathrm{c}}$ & $166.82 \pm 0.00^{\mathrm{b}}$ & $149.57 \pm 1.23^{\mathrm{b}}$ & $163.01 \pm 1.92^{\mathrm{a}}$ & $123.35 \pm 2.35^{\mathrm{a}}$ \\
\hline Flowers & $169.17 \pm 2.35^{\mathrm{b}}$ & $112.64 \pm 1.11^{\mathrm{a}}$ & $173.86 \pm 0.00^{\mathrm{c}}$ & $116.7 \pm 2.06^{\mathrm{b}}$ & $167.26 \pm 3.69^{\mathrm{a}}$ & $116.7 \pm 1.89^{b}$ \\
\hline \multirow[t]{3}{*}{ Fruits } & - & - & - & - & - & - \\
\hline & \multicolumn{6}{|c|}{ Fruiting phase } \\
\hline & TP & SP & TP & SP & TP & SP \\
\hline Roots & $144.42 \pm 1.6^{c}$ & $35.89 \pm 2.59^{\mathrm{a}}$ & $83.59 \pm 0.29^{\mathrm{a}}$ & $48.09 \pm 0.76^{\mathrm{b}}$ & $97.08 \pm 0.66^{\mathrm{b}}$ & $57.33 \pm 0.34^{c}$ \\
\hline Branches & $113.34 \pm 1.29^{c}$ & $61.81 \pm 0.67^{c}$ & $95.28 \pm 1.08^{\mathrm{a}}$ & $55.63 \pm 1.6^{\mathrm{b}}$ & $99.68 \pm 1.31^{\mathrm{b}}$ & $42.15 \pm 0.34^{\mathrm{a}}$ \\
\hline Leaves & $149.86 \pm 3.33^{\mathrm{a}}$ & $132.97 \pm 0.73^{b}$ & $164.91 \pm 1.91^{\mathrm{c}}$ & $132.24 \pm 0.00^{\mathrm{a}}$ & $157.86 \pm 1.62^{\mathrm{b}}$ & $134.42 \pm 0.00^{\mathrm{c}}$ \\
\hline Flowers & - & - & - & - & - & - \\
\hline Fruits & $158.36 \pm 4.4^{\mathrm{a}}$ & $94.42 \pm 1.55^{\mathrm{b}}$ & $169.17 \pm 2.35^{\mathrm{c}}$ & $94.54 \pm 0.58^{\mathrm{c}}$ & $164.91 \pm 1.91^{\mathrm{b}}$ & $80.6 \pm 0.37^{\mathrm{a}}$ \\
\hline \multicolumn{7}{|c|}{$\begin{array}{l}\text {-A: Mountain, B: Pla } \\
\text {-TP: total protein } \\
\text {-SP: soluble protein }\end{array}$} \\
\hline
\end{tabular}

TABLE 5. Variations in the mean concentration $(\mathrm{mg} / \mathrm{g}$.d.wt) \pm SD of essential elements in different organs of Rhazya stricta during vegetative phase in different habitats.

\begin{tabular}{lcccccc}
\hline \multirow{2}{*}{ Elements } & \multicolumn{2}{c}{ A } & \multicolumn{2}{c}{ B } & \multicolumn{2}{c}{ C } \\
\cline { 2 - 6 } & Roots & Leaves & Roots & Leaves & Roots & Leaves \\
\hline $\mathrm{Ca}^{+2}$ & $30.25 \pm 3.25^{\mathrm{ab}}$ & $132.25 \pm 3.25^{\mathrm{b}}$ & $42.50 \pm 4.0^{\mathrm{a}}$ & $141.25 \pm 2.7^{\mathrm{b}}$ & $21.75 \pm 0.75^{\mathrm{b}}$ & $192.50 \pm 1.50^{\mathrm{a}}$ \\
$\mathrm{Mg}^{+2}$ & $6.75 \pm 0.75^{\mathrm{b}}$ & $23.75 \pm 0.75^{\mathrm{c}}$ & $14.50 \pm 0.50^{\mathrm{a}}$ & $27.0 \pm 0.50^{\mathrm{b}}$ & $8.75 \pm 0.25^{\mathrm{b}}$ & $35.25 \pm 0.75^{\mathrm{a}}$ \\
$\mathrm{Na}^{+1}$ & $7.50 \pm 0.50^{\mathrm{a}}$ & $21.0 \pm 2.29^{\mathrm{a}}$ & $4.75 \pm 0.25^{\mathrm{b}}$ & $6.67 \pm 0.73^{\mathrm{b}}$ & $0.65 \pm 0.10^{\mathrm{c}}$ & $0.60 \pm 0.03^{\mathrm{c}}$ \\
$\mathrm{K}^{+1}$ & $47.0 \pm 6.50^{\mathrm{b}}$ & $89.25 \pm 0.25^{\mathrm{c}}$ & $163.5 \pm 13.50^{\mathrm{a}}$ & $248.75 \pm 3.25^{\mathrm{a}}$ & $71.75 \pm 6.25^{\mathrm{b}}$ & $116.25 \pm 2.25^{\mathrm{b}}$ \\
$\mathrm{P}=$ & $5.18 \pm 0.58^{\mathrm{b}}$ & $9.88 \pm 0.48^{\mathrm{b}}$ & $13.48 \pm 2.98^{\mathrm{a}}$ & $13.38 \pm 0.63^{\mathrm{a}}$ & $6.50 \pm 0.30^{\mathrm{ab}}$ & $7.23 \pm 0.13^{\mathrm{c}}$ \\
\hline
\end{tabular}

-A: Mountain, B: Plain, C: Wadi

-Different letters for each organ respecting the three different habitats for each parameter indicate a significant difference at the 0.05 level of probability as evaluated byas evaluated by analysis of variance. 
TABLE 6. Qualitative phytochemical screening in different organs of Rhazya stricta during vegetative phase in different habitats.

\begin{tabular}{lcccccc}
\hline \multirow{2}{*}{ Components } & \multicolumn{2}{c}{ A } & \multicolumn{2}{c}{ B } & \multicolumn{2}{c}{ C } \\
\cline { 2 - 7 } & Roots & Leaves & Roots & Leaves & Roots & Leaves \\
\hline Alkaloids & +++ & +++ & ++ & ++ & + & ++ \\
Coumarins & + & + & + & + & + & + \\
Essential oil & ++ & +++ & - & - & ++ & +++ \\
Flavonoides & ++ & ++ & + & + & + & ++ \\
Glysosides & +++ & +++ & ++ & ++ & + & + \\
Phenolics & + & ++ & + & + & - & - \\
Saponins & + & + & - & - & - & - \\
Sterols & ++ & +++ & ++ & ++ & + & + \\
Tannins & ++ & ++ & + & + & + & + \\
\hline
\end{tabular}

-A: Mountain, B: Plain, C: Wadi

+ positive, ++ strongly positive, +++ extremely positive, - negative

TABLE 7. Variations in the content (\%) of some active phytochemical compounds in different organs of Rhazya stricta during vegetative phase in different habitats.

\begin{tabular}{lcccccc}
\hline \multirow{2}{*}{ Components } & \multicolumn{2}{c}{ A } & \multicolumn{2}{c}{ B } & \multicolumn{2}{c}{ C } \\
\cline { 2 - 7 } & Roots & Leaves & Roots & Leaves & Roots & Leaves \\
\hline Total flavonoids (\%) & 2.335 & 2.967 & 1.617 & 1.700 & 1.533 & 1.467 \\
Total phenolics (\%) & 10.326 & 11.321 & 7.575 & 7.360 & 9.00 & 9.234 \\
$\begin{array}{l}\text { Essential oil } \\
\text { (ml/100g.d. wt.) }\end{array}$ & 0.03 & 0.04 & 0.01 & 0.01 & 0.02 & 0.02 \\
Alkaloids (\%) & 0.10 & 0.81 & 0.40 & 0.80 & 0.75 & 0.79 \\
\hline
\end{tabular}

-A: Mountain, B: Plain, C: Wadi-

In the study area, the obtained data revealed that the three studied habitats differed from one to another especially in their soil characters. Schoenholtz et al. (2000) reported that soil texture was the most fundamental soil physical property controlling water moisture availability, nutrient content, distribution of plant species and their roots, oxygen exchange and uptake as well as influences the growth vegetation pattern (Fisher \& Binkley, 2000). The present results indicated that the soil characters in the different studied habitats were affected on plant growth and productivity of $R$. stricta. Whereas, these parameters were high in wadi which characterized with sandy soil (high coarse sand) associated with low moisture, high content of $\mathrm{Ca}^{++}, \mathrm{K}^{+}$and low content of $\mathrm{Na}^{+}$, $\mathrm{Cl}^{-}$. Also, plain was suitable habitat for the plant growth and productivity but its soil characterized by the highest moisture content, sandy soil (high fine sand), high content of $\mathrm{Mg}, \mathrm{Na}$ and low $\mathrm{Ca}$. Concerning to the mountain, it attained the lowest plant growth and productivity due to exposed the plant to mechanical stress which resulted from great stones hindered the root penetrations and led to a remarkable reduction in these parameters. Passioura (2002) reported that plants can respond to soil conditions in ways that cannot readily be explained in terms of the ability of the roots to take up water and nutrients. Roots may sense difficult conditions in the soil and hence send inhibitory signals to the shoots which harden the plants against the consequences of a deteriorating or restrictive environment, especially if the plants' water supply is at risk. The inhibitory signals may affect stomatal conductance, cell expansion, cell division and the rate of leaf appearance which 
probably signifies that a network of hormonal and other responses is involved in attuning the growth and development of a plant to its environment.

The variations in the soil characters were affected on the plant morphology of the same species in the different habitats which still need more attention (Dunn \& Sharitz, 1991 and Taia \& ElGhanem, 2004). The physiological and morphological characteristics as well as yield are influenced not only by the genetic but also by environmental conditions which can result in biochemical and physiological alterations in plants (Sangwan et al., 2001). In the present study, the change in morphological characters of the plant such as leaf area, height of plant, crown diameter and also the biomass of most above ground organs, attained their highest values in plain followed by wadi and the least one was in mountain.Khakdan et al. (2012) stated that,the primary response of plants to stress is the inhibition of shoot growth, allowing activating genes that producing cellular essential solutes to be diverted from growth requirements to stress-related functions.

The chlorophyll content in $R$. stricta changed with habitat variations during the vegetative phase, whereas leaf chlorophyll has been used to quantify photosynthetic health of plants (Wittmann et al., 2001). Chlorophyll content was the highest in mountain which may indicate the presence of protection mechanism of chloroplast under stress (Chaves et al., 2009 and Morsy, 2008). The content of chlorophyll $\mathrm{a}$ and $\mathrm{b}$ in plants grown in plain was the lowest. Jason et al. (2004) reported that decreases in $\mathrm{Chl} \mathrm{b}$ content is an indicator of chlorophyll destruction by excess irradiance. Also, indicating that the chlorophyll content might be contributed to the difference in the photosynthetic capacity among the environmental conditions. The role of pigments in plant processes is indispensable, whereas the synthesis of photosynthetic pigments is genetically controlled, but it also depends on environmental factors.

The content of carbohydrates and proteins in most plant organs varied significantly with habitat in each phenophase (vegetative, flowering and fruiting phase). Carbohydrates (total and soluble) in most plant organs attained their minimum in mountain and maximum in plain and wadi. Zhonghua et al. (2007) stated that plants employ various strategies to overcome stress conditions. One common mechanism is the accumulation of compatible solutes which often regarded as a basic strategy for protection and survival of plants under abiotic stress. For instance, accumulation of soluble sugars is necessary to regulate osmotic activities and protect cellular structures by maintaining the cell water balance, membrane stability (Farooq et al., 2008). Roitsch \& González (2004) stated that sucrose and its cleavage products regulate plant development and response to stresses through carbon allocation and sugar signaling. Mohamed \& Alain (1995) suggested that the accumulation of carbohydrates under stress being due to reduction in their utilization, either as a source of energy or for the formation of new cells and tissues. On the other hand, Khakdan et al. (2012) reported that under the diverse environmental stresses often activate similar cell signaling pathways and cellular responses, such as the production of stress proteins, up- regulation of anti- oxidant and accumulation of compatible solutes. AboKassem et al. (2002) reported that high salt concentration can result in osmotic adjustment by regulating the accumulation of solutes especially sugars and proteins. In the present study, the plant which grow in mountain and subjected to severe mechanical stress attained high content of protein. Among general stress tolerance mechanisms, stress proteins, osmo-protectants, free-radical scavengers, ion transporters and factors involved in signaling cascades and transcriptional control are essential to counteract stress effects (Wang et al., 2004).

Drought and soil salinity due to high surface evaporation are important factors in desert ecosystem affecting nutrient absorption (Breckle, 2002 and Marchin et al., 2010). The obtained results revealed that, the change in habitats has greet effect on the accumulation of essential elements in roots and leaves of the studied plant. $\mathrm{K} / \mathrm{Na}$ ratio was low for the plant organs (roots, leaves) in mountain. This allows the plant to use $\mathrm{Na}$ as the major osmoregulatory substance, while in plain and wadi $\mathrm{K} / \mathrm{Na}$ ratio was high, this means the contribution of $\mathrm{K}$ to the osmotic balance is larger than $\mathrm{Na}$ (Adams \& Shin, 2014).

Xerophytic plants have evolved numerous adaptive strategies which enable them to survive the harsh environmental conditions including the production of diverse secondary metabolites (Barbara et al., 2013). These metabolites such as phenolics, flavonoids, anthocyanins, and plant steroids can accumulate in certain plant organs 
such as leaves, fruits, roots and stems. As a large group of bioactive chemicals which have diverse biological functions (Simonetti et al., 2001). Therefore, these compounds are essential to plant life, possessing varying degrees of diseasepreventive properties, act as defense mechanisms against environmental stress (Oliveira et al., 2014). Phytochemical components in leaves and roots of $R$. stricta which known to have high antioxidant activity exhibited great variations with different studied habitats. In mountain habitat which characterize by reduction in plant growth under mechanical stress have existed the highest values of total phenolics and total flavonoids. This may be as a result build up a substrate for lignin synthesis which could be shunted into the production of secondary phenolic compounds (Barbara et al., 2013). Flavonoids also are regarded as one of the most widespread groups of natural constituents found in the plants. Flavonoids show antioxidant activity through scavenging or chelating process (Pourmorad et al., 2006). The results in the current study showed that $R$. stricta considered as a good source of phytochemical compounds especially which adapted to mountain habitat. These findings may explain their extensive uses in folk medicine.

\section{Conclusion}

The growth and metabolic behavior of desert plants in relation to environmental factors such as habitat variation are complicated. The present study concluded that there are greater sensitivity of perennial shrub $R$. stricta to change with different habitats which demonstrated by morphological and physiological variations. The highest growth of plant was in plain and wadi which characterized by sandy soil but the lowest was in mountain where the plant was subjected to mechanical stress due to the presence of large stone which formed the mountain. Plant in mountain habitat adapted this stress by increase the protein content in its organs, increase the phenolics and flavonoids.

\section{References}

Abo-Kassem, E.M., Kasim, W.A. and Hamada, E.A.M. (2002) Effect of three potassium salts on some metabolites and enzyme activities in Raphanus sativus, L. Seedlings. Proc. $2^{\text {nd }}$ Int. Conf. Biol. Sci., (ICBS) Fac. Sci., Tanta, pp. 409-420.

Adams, E. and Shin, R. (2014) Transport, signaling, and homeostasis of potassium and sodium in plants. $J$.
Integr. Plant Biol. 56, 231-249.

Allen, S.E., Grimshaw, H.M., Parkinson, J.A. and Quarmby, C. (1984) "Chemical Analysis of Ecological Materials", Blackwell Scientific Publications, Oxford London, Edinburgh, Melbourne, 565 pp.

Barbara, N.T., Cornelius, S. and Frank, A.L. (2013) Phytochemical Adaptations to Stress, Volume 18 of "Recent Advances in Phytochemistry", Springer Science \& Business Media, 334 pp.

Bita, C.E. and Gerats, T. (2013) Plant tolerance to high temperature in a changing environment: Scientific fundamentals and production of heat stress-tolerant crops. Front Plant Sci. 4, 273.

Breckle, S.W. (2002) "Salinity, Halophytes and Salt Affected Natural Ecosystems". Springer

Causton, D.R. (1988) "Introduction to Vegetation Analysis" $1^{\text {st }}$ ed. Academic Division of Unv. In Hyman Ltd. pp. 341.

Chaudhary, S.A. and Al-Jowaid, A.A. (1999) "Vegetation of the Kingdom of Saudi Arabia", Ministry of Agriculture \& Water, Riyadh, 689 p.

Chaves, M.M., Flexas, J. and Pinheiro, C. (2009) Photosynthesis under drought and salt stress: Regulation mechanisms from whole plant to cell. Ann. Bot. 2009 Feb; 103(4), 551-560.

Chaves, M.M., Maroco, J.P. and Pereira, J.S. (2003) Understanding plant response to drought-from genes to the whole plant. Funct. Plant Biol. 30, 239-264.

Dunn, C.P. and Sharitz, R.R. (1991) Population structure, biomass allocation and phenotypic plasticity in Murdannia keisak (Commelinaceae), American J. Bot. 78, 1712-1723.

Farnsworth, N.R. (1966) Biological and phytochemical screening of plants. J. Pharm. Sci. 55, 225-276.

Farooq, M., Basra, S., Wahid, A., Cheema, Z., Cheema, M. and Khaliq, A. (2008) Physiological role of exogenously applied glycinebetaine to improve drought tolerance in fine grain aromatic rice (Oryza sativa L.). J. Agron. Crop Sci. 194, 325-333.

Fisher, R.F. and Binkley, D. (2000) "Ecology and 
Management of Forest Soils". $3^{\text {rd }}$ ed. John Wiley and Sons, UK., Pages: 78 genotypes. J. Agric. Food Chem. 56, 696-704.

Gilani, S.A., Kikuchi, A., Shinwari, Z.K., Khattak, Z.I. and Watanabe, K.N. (2007) Phytochemical, pharmacology and ethnobotanical studies of Rhazya stricta Dence, Phytother, Res. 21, 301-307.

Hale, M.G. and Orcutt, D.M. (1987) "The Physiology of Plants under Stress". A Wiley-Interscience Publication, John-Wiley and Sons, New York.

Harborne, J.B. (1973) "Phytochemical Methods: A Guide to Modern Techniques of Plant Analysis". Chapman and Hall, London, p. 279.

Harborne, J.B. (1998) "Phytochemical Methods: A Guide to Modern Techniques of Plants Analysis", $2^{\text {nd }}$ ed. Chapman and Hall, London, pp. 54-84.

Harborne , J.B. (1999) Classes and functions of secondary products from plants. In: "Chemicals from Plants-Perspectives on Plant Secondary Products" Walton, N.J., Brown, D.E. (Ed.), pp. 1-25. Imperial College Press, London.

Hartree, E.F. (1972) A modification of the Lowery method that gives a linear photometric response, Anal. Biochem. 48(2), 422-427.

Jason, J.G., Thomas, G.R. and Pharr, D.M. (2004) Photosynthesis, chlorophyll fluorescence and carbohydrate content of Illicium taxa grown under varied irradiance. J. Am. Soc. Hort. Sci. 129, 46-53.

Khakdan, F., Moshtaghi, N. and Piri , K . (2012) Increment of abiotic stress tolerance by metabolic engineering of compatible solutes. Intl. J. Agri. Crop Sci. 4(24), 1856-1866.

Kilmer, V.J. and Alexander, L.T. (1949) Methods of makings mechanical analysis of soils. Soil Sci. 68, 15-24.

Krasensky, J. and Jonak, C. (2012) Drought, salt, and temperature stress-induced metabolic rearrangements and regulatory networks. J. Exp Bot. 63(4), 1593-608.

Larcher, W. (1995) "Physiological Plant Ecology", 3rd ed, Berlin, Heidelberg, New York: pringer-Verlag.

Lewis, H. and Smith, C. (1967) Sugars alcohol in fungi and green plants. Methods of detection and estimation. New Phytol. 66, 185-204.

Lichtenthaler, H.K. (1987) Chlorophylls and carotenoids: Pigment of photosynthetic biomembranes, Methods Enzymol.148, 30-382.

lowry, O.H., Rosebrough, N.J., Farr, A.L. and Randall, R.J. (1951) Protein measurement with the Folin phenol reagent. J. Biol. Chem. 193(1), 265-75.

Marchin, R., Zeng, H. and Hoffmann, W. (2010) Drought-deciduous behavior reduces nutrient losses from temperate deciduous trees under severe drought. Oecologia, 163, 845 (2010).

Meda, A., Lamien, C.E., Romito, M., Millogo, J. and Nacoulma, O.G. (2005) Determination of the total phenolic, flavonoid and proline contents in Burkina Fasan honey, as well as their radical scavenging activity. Food Chem. 91, 571-577.

Meteorology and Environment (1992) Red Sea, Saudi Arabia of coastal and marine habitats of Red Sea Meteorology and Environment Protection administration. Ministry of Defense and Aviation Kingdom of Saudi Arabia.

Mesdaghi, M. (1995) "Range Management in Iran". Astane Ghodse Razavi Press.

Migahid, A.M. (1996) "Flora of Saudi Arabia", $4^{\text {th }}$ ed, King Saud University Press, Riyad

Mohamed, N. and Alain, C. (1995) Effect of sodium chloride on growth, tissue elasticity and solute adjustment in two Acacia nilotica sub-species. Phyiol. Plant. 93, 217-224.

Morsy, A.A. (2008) Ecophysiological studies on Atriplex farinose Forssk. Under different habitats conditions. Australian Journal of Basic and Applied Sciences, 2(2), 272-281.

Naguib, M.I. (1964) Effect of sevin on the carbohydrate and nitrogen metabolism during the germination of cotton seeds, Ind. J. Exp. Biol. 2,149-154.

Nelson, N. (1944) A photometric adaptation of the Somogyi method for the determination of glucose, J.Biol. Chem. 153, 375-380.

Odalo, J.O., Omolo, M.O., Malebo, H., Angira, J., Njeru, P.M., Ndiege, I.O. and Hassan, A.A. (2005) 
Repellency of essential oils of some plants from the Kenyan coast against Anopheles gambiae. Acta Trop. 95, 210-218.

Oliveira, Lívia de Lacerda de, Carvalho Mariana Veras de and Melo Lauro (2014) Health promoting and sensory properties of phenolic compounds in food. Food Science and Tecnology. 61, suppl.,764-779.

Passioura, J.B. (2002) Soil conditions and plant growth. Plant, Cell and Enveronment, 25, 311-318.

Pourmorad, F., Hosseinimehr, S.J. and Shahabimajd, N. (2006) Antioxidant activity, phenol and flavonoid contents of some selected Iranian medicinal plants. African Journal of Biotechnology, 5(11), 1142-1145.

Raven, P. and Johnson, G.B. (2002) "Biology", $6^{\text {th }}$ ed. McGraw Hill, Dubuque, 1238 pp.

Roitsch, T. and González, M.C. (2004) Function and regulation of plant invertases: Sweet sensations. Trends Plant Sci. 9, 606-613.

Sangwan, N.S., Farooqi, A.H.A., Shabin, F. and Sangwan, R.S. (2001) Regulation of essential oil production in plants. J. Plant Growth Regul. 34, $3-21$.

Schoenholtz, S.H., Van Miegroet, H. and Burger, J.A. (2000) A review of chemical and physical properties as indicators of forest soil quality: Challenges and properties. For. Ecol. Manage. 138, 335-356.

Simonetti, P., Gardana, C. and Pietta, P. (2001) Plasma level of caffeic acid and antioxidant status after red wine intake. J. Agric. Food Chem. 49, 5964-5968.

Taia, W.K. and El-Ghanem, W.M. (2004) Effect of habitats on both the phenotypic characters and mineral contents of five wild species in El-Riyadh city. Pakistan Journal of Biological Sciences, 7(8), 1399-1403.

Tony, H. and Norio, M. (2002) Enhancement of tolerance of abiotic stress by metabolic engineering of betaines and other compatible solutes. Current Opinion in Plant Biology, 5, 250-257.

Wang, X., Liu, L., Liu, S., Sun, X., Deng, Z. and Pi, Y. (2004) Isolation and molecular characterization of a new CRT binding factor gene from Capsella bursapastoris. J. Biochem. Mol. Biol. 37, 538-545.

Wittmann, C., Aschan, G. and Pfanz, H. (2001) Leaf and twig photosynthesis of young beech (Fagus sylvatica) and aspen (Populus tremula) trees grown under different light regime. Basic Appl. Ecol. 2, $145-154$.

Zahran, M.A. (2010) "Climate - Vegetation: AfroAsian Mediterranean and Red Sea Coastal Lands". Springer Dordrecht Heidelberg, London.

Zar, J.H. (1984) "Biostatistical Analysis". Prentice-Hall: Inc., New Jersey, p.718.

Zhonghua, C., Tracey, A., Cuin, M., Amanda, T., Bodapati, P. and Shabala, S. (2007) Compatible solute accumulation and stress- mitigating effects in barley genotypes contrasting in their salt tolerance. Journal of Experimental Botany, 58(15/16), 42454255 .

(Received $3 / 11$ / 2017; (accepted 6/2/2018 


\section{تأثثير اختلاف المواطن البيئية على النمو ونواتج الأيض في نبات الحرمل في منطقة مكة ـ المملكة العربية السعودية الموافية}

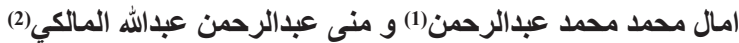

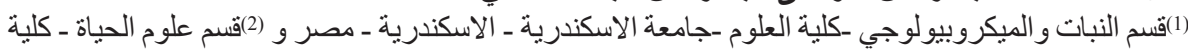
العلوم - جامعة ام القرى ـ مكة المكرمة ــ السعودية.

يهدف هذا البحث إلى توضيح ودر اسة العلاقة بين التنوع البيئى لنبات صحر اوي معمر في بيئات مختلفة ومظاهر

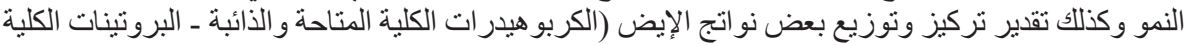
و الذائبة ـ المركبات الثانوية ـ المعادن الأساسية و الضرورية للنمو ) داخل انسجة و أعضاء النبات في مر احل

نمو مختلفة.

ولتحقيق هذا الهدف اختير لهذه الدر اسة نبات الحرمل الشجيري المعمر وثثلاث مو اطن بيئية مختلفة خاصة

في صفات التربة هم السهل و الو ادي و الجبل في منطقة مكة المكرمة بالسعودية.

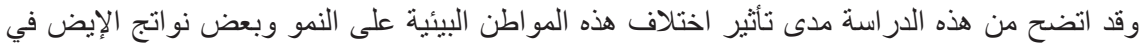

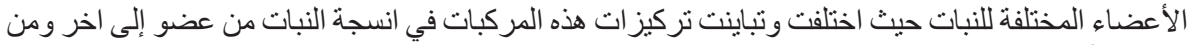

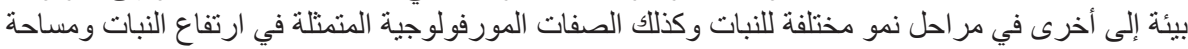
الأوراق و عرض التاج و انتاجية النبات

و أظهرت الدر اسة أن أعلى نمو وكثافة وتردد و غطاء و انتاجية للنبات كانت في الو ادي و السهل و اعزي ذللك إلى صفات التربة في هذه المو اطن. ألى

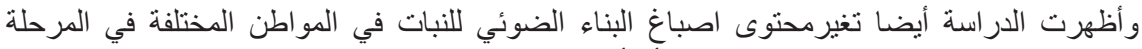

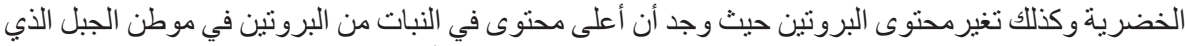

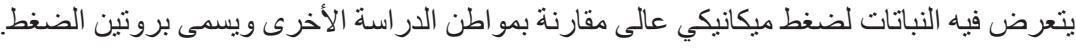

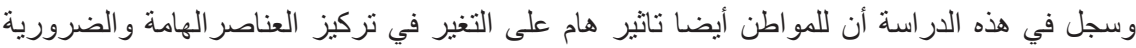

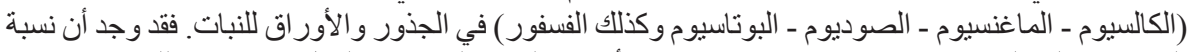

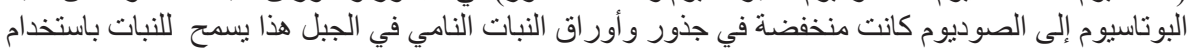

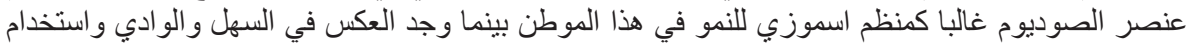
النبات لعنصر البوتاسيوم كمنظم اسموزي.

وللنباتات الصحر اوية عدد من استراتيجيات التكيف والتي تمكنها من النمو و البقاء تحت الظروف التهات البيائية

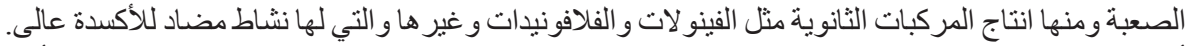

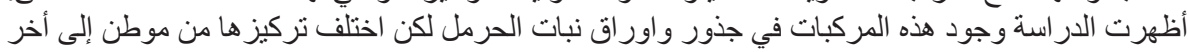

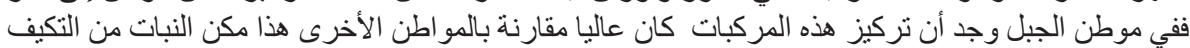

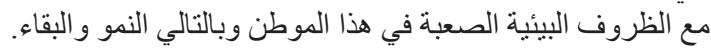

مما سبق يمكن استنتاج أن البيئات المختلفة بخصائصها المتباينة وخاصة في الصفات الطبيعية و الكيميائية

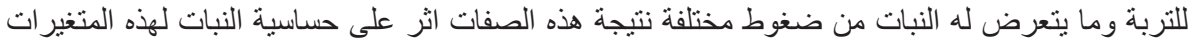

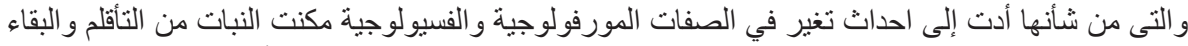

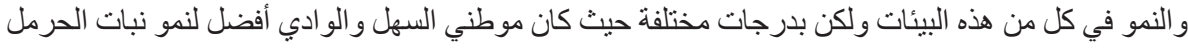
من موطن الجبل. 